\title{
SPDEF wt Allele
}

National Cancer Institute

\section{Source}

National Cancer Institute. SPDEF wt Allele. NCI Thesaurus. Code C102919.

Human SPDEF wild-type allele is located in the vicinity of $6 \mathrm{p} 21.3$ and is approximately 19 $\mathrm{kb}$ in length. This allele, which encodes SAM pointed domain-containing Ets transcription factor, plays a role in transcriptional regulation. 